\title{
ERRATUM
}

\section{Tales of future weather}

W. Hazeleger, B. J. J. M. van den Hurk, E. Min, G. J. van Oldenborgh, A. C. Petersen, D. A. Stainforth, E. Vasileiadou and L. A. Smith

Nature Clim. Change 5, 107-114 (2015); published online 28 January 2015; corrected after print 28 January 2015

In the print version of this Perspective, the last sentence in Box 1 was cut off, and should have read "The model information of this specific case added with 'what-if' scenarios of sea-level rise and on changes in extreme rainfall have been provided to water managers and now aid in designing adaptation measures in a realistic setting." This error has been corrected in the online versions. 